Adji, T. N., Sudarmadji, Woro, S. Hendrayana, H.. 2006. The Distribution of Flood Hydrograph Recession Constant Of Bribin River For Gunung Sewu Karst Aquifer Characterization. GunungSewu-Indonesian Cave and Karst Journal (Vol.2. No.2)

\title{
Perhitungan Konstanta Resesi Akuifer Karst Sepanjang Aliran Sungai Bribin, Gunung Sewu
}

\author{
Tjahyo Nugroho Adji, Sudarmadji, Suratman Woro, Heru Hendrayana \\ Kelompok Studi Karst, Fakultas Geografi UGM, Yogyakarta, 55281 \\ Telp. :62-8122967492 ; email:adji @geo.ugm.ac.id
}

\begin{abstract}
Abstrak
Penelitian ini dilakukan pada 3 gua sepanjang Sungai bawahtanah Bribin, di wilayah karst Gunung Sewu, Kabupaten Gunung Kidul. Tujuan dari penelitian ini adalah untuk mengidentifikasi parameter dari Sungai Bribin untuk mengkarakterisasi sifat akuifer karst. 3 logger pencatat tinggi muka air dipasang, yaitu di Gua Gilap, Bribin, dan Ngreneng. Selanjutnya, pengukuran debit aliran secara temporal pada saat-saat aliran minimum, rata-rata, dan banjir dilakukan untuk membuat kurva hubungan tinggi muka air dan debit, sehingga debit aliran sepanjang tahun dapat dihitung. Kemudian, beberapa banjir terseleksi sepanjang tahun dihitung nilai konstanta resesinya yang meliputi resesi aliran diffuse $\left(\mathrm{K}_{\mathrm{c}}\right)$, resesi aliran fissure $\left(\mathrm{K}_{\mathrm{i}}\right)$, dan resesi aliran conduit $\left(\mathrm{K}_{\mathrm{c}}\right)$. Hasil perhitungan menunjukkan bahwa Gua Gilap yang terletak pada bagian atas Sungai Bribin mempunyai respon banjir tercepat terhadap hujan. Perhitungan nilai resesi diffuse juga menunjukkan nilai yang terkecil $\left(\mathrm{K}_{\mathrm{b}}=0,994\right)$, dibandingkan dengan Bribin $(0,998)$, dan Ngreneng $(0,997)$. Hal ini menunjukkan bahwa akufer di sekitar Gua Gilap melepaskan simpanan airtanah lebih cepat dibanding 2 gua yang lain. Kebalikannya, Gua Bribin menunjukan nilai tertingi pada resesi diffuse $(0,998)$ dan fakta ini ditunjukkan dengan nilai minimum debitnya pada puncak musim kemarau yang masih mencapai diatas 1500 liter/detik.
\end{abstract}

Kata kunci : karts , akuifer, konstanta resesi

\begin{abstract}
This research is carried out within three caves along Bribin River, which is located in Gunung Sewu karst area, Gunung Kidul. The objective of this research is to identify some flood hydrograph properties of Bribin River with the intention of karst aquifer characterization. Water level data loggers are installed within three caves represent upper part, lower part, and leakage of Bribin River, which are Gilap, Bribin, and Ngreneng Cave, respectively. In addition, time series discharge measurement in correspond to minimum, average, and maximum flow events is conducted to formulate the Annual Stage Discharge Rating Curve. Thereby, the full year river hydrograph may be defined. Afterwards, by selecting several flood hydrograph events, the recession constant in each cave including diffuse flow recession $\left(\mathrm{K}_{\mathrm{b}}\right)$, fissure flow $\left(\mathrm{K}_{\mathrm{i}}\right)$, and conduit flow $\left(\mathrm{K}_{\mathrm{c}}\right)$, is then calculated and compared in every caves. The result shows that Gilap Cave that represents the upper part of Bribin River confirms the quickest respond towards rainfall events. Also, this point specifies the least number of diffuse recession constant $\left(\mathrm{K}_{\mathrm{b}}=0.994\right)$, compared to Bribin (0.998), and Ngreneng (0.997), means that the aquifer surrounding Gilap Cave release its groundwater storage faster than Bribin and Gilap Cave. On the contrary, Bribin Cave performs the highest value of diffuse recession constant (0.998) and this situation is confirmed by its dry season discharge that still above 1500 lt/second.
\end{abstract}

Kata kunci : karts , aquifer, recession constant 
Adji, T. N., Sudarmadji, Woro, S. Hendrayana, H.. 2006. The Distribution of Flood Hydrograph Recession Constant Of Bribin River For Gunung Sewu Karst Aquifer Characterization. GunungSewu-Indonesian Cave and Karst Journal (Vol.2. No.2)

\section{Pendahuluan}

Karakterisasi akuifer karst oleh sebagian besar hidrolog dianggap tidak mudah karena sifatnya yang heterogen dan anisotropis (Ford and Williams1992). Oleh Blair (2004) hal ini malah dianggap sebagi suatu keunikan dibanding karakter pada jenis akuifer lain, karena kuatnya kontrol dari struktur geologi. Struktur yang dimaksud disini adalah karena sifat dan efek deformasi dari material batuan dasar (Haryono and Adji, 2004; Adji and Hayono, 1999; Adji et al, 1999). Batuan gamping di dekat permukaan tanah mempunyai kecenderungan terhadap terjadinya retakan, dan karena proses lanjut dari pelarutan air hujan kemudian membentuk retakan-retakan ke berbagai arah (joint) yang tidak beraturan atau yang dikenal sebagai conduit atau porositas sekunder. Gambar 1 selanjutnya menunjukkan perbedaan antara porositas pada akuifer karst dan akuifer selain karst.

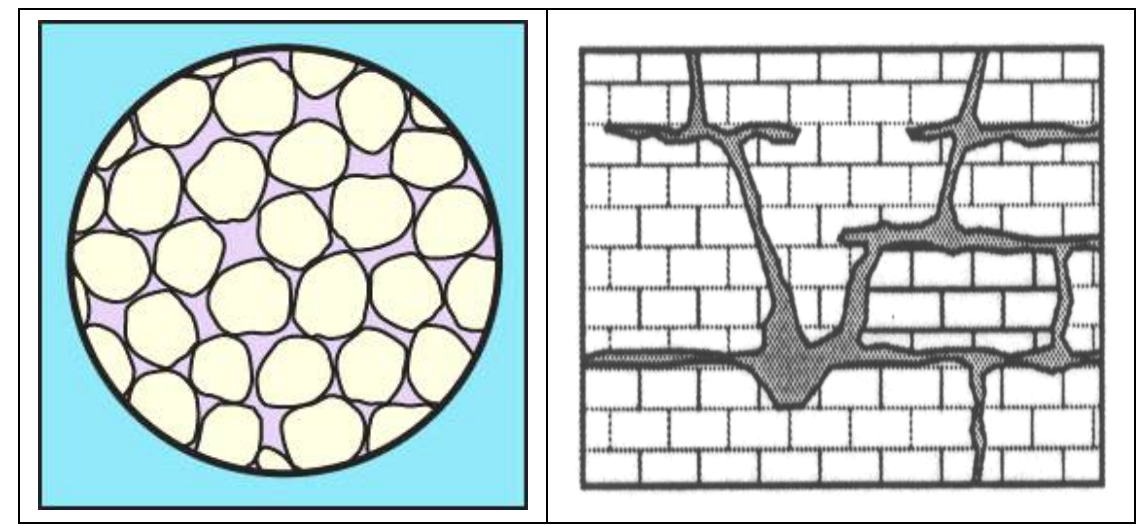

Gambar 1. Perbedaan porositas di akuifer isotropik non-karst (kiri), dan anisotropik di akuifer karst (kanan)

Lebih jauh lagi, White (1988), Ford and Williams (1992), Smart and Hobbes (1986) serta Gillieson (1996) secara prinsip membagi sifat aliran pada akuifer karst menjadi tiga komponen yaitu :aliran saluran/lorong (conduit), celah (fissure), dan rembesan (diffuse). Sementara itu, oleh Domenico and Schwarts (1990), komponen aliran di akuifer karst hanya dibedakan menjadi dua yaitu komponen aliran rembesan (diffuse) dan saluran (conduit), seperti yang ditunjukkan pada Gambar 2. Komponen aliran diffuse diimbuh oleh air infiltrasi yang tersimpan pada bukit-bukit karst (Haryono, 2001) dan mengisi sungai bawah tanah karst sebagai tetesan dan rembesan pada ornamen gua. Komponen aliran ini bersifat laminar dan karakterisasinya dapat mengikuti hukum Darcy (White, 1993). Sementara itu, komponen aliran conduit mendominasi sungai bawah tanah terutama pada saat banjir dan responnya terhadap hujan hampir menyerupai sungai bawah tanah karena diimbuh oleh aliran permukaan yang masuk ke akuifer karst melalui ponor atau sinkhole. Sifat aliran ini adalah turbulent dan hukum Darcy tidak dapat diterapkan untuk mengkarakterisasinya (Jankowski, 2001).

Karena keunikan sifat akuifer serta komponen alirannya, maka hampir semua penelitian hidrologi di akuifer karst tidak menggunakan metode penelitian yang bersifat deduktif (mengunakan distribusi sifat permukaan untuk mengkarakterisasi sifat alirannya), tetapi lebih cenderung menggunakan sifat penelitian Quasi-Experimental Research (Dane, 1990), dengan metode survei induktif pada sungai bawah tanah. Beberapa penelitian terdahulu yang menggunakan metode induktif diantaranya adalah Anthony et al. (1997), Karimi et al. (2004), Liu et al. (2004 a\&b), Raeisi dan Karami (1997), serta Etfimi (2005). Penelitian-penelitian yang 
Adji, T. N., Sudarmadji, Woro, S. Hendrayana, H.. 2006. The Distribution of Flood Hydrograph Recession Constant Of Bribin River For Gunung Sewu Karst Aquifer Characterization. GunungSewu-Indonesian Cave and Karst Journal (Vol.2. No.2)

disebutkan ini diantaranya mengunakan pendekatan hidrogeokima pada titik-titik tertentu sungai bawah tanah, serta beberapa peneliti lain menggunakan metode hidrograf aliran dan respon aliran terhadap hujan untuk mengkarakterisasi perilaku akuifer karst.
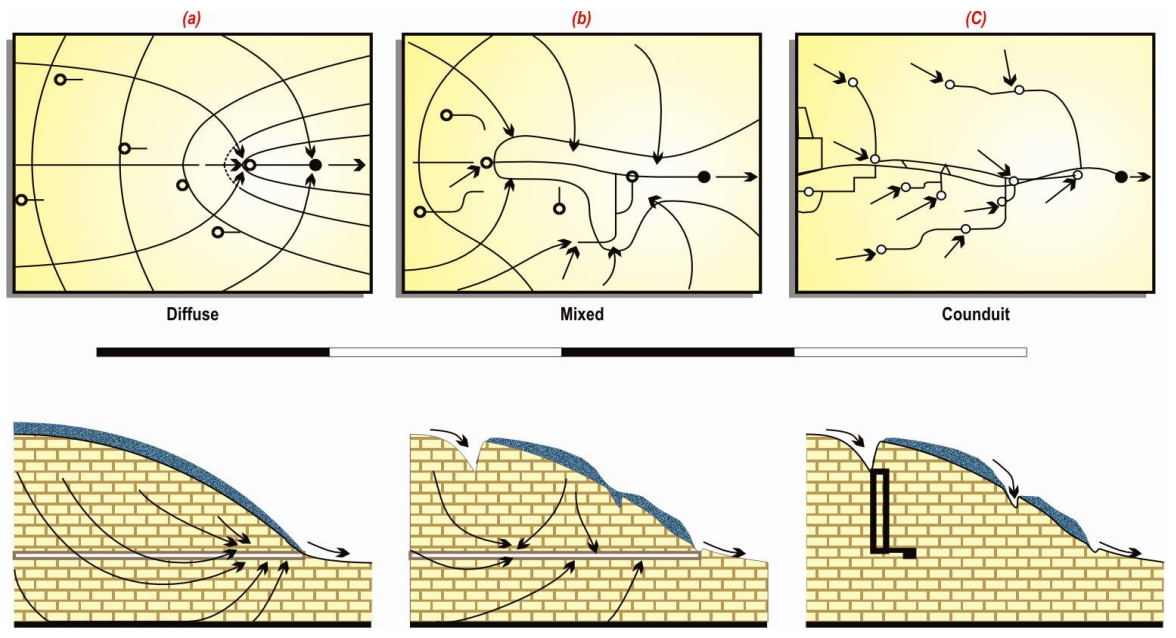

Gambar 2. Diffuse, mixed dan conduit aliran airtanah karst (Domenico and Schwartz, 1990)

\section{Resesi Konstant Pada Hidrograf Banjir}

Jika pada suatu aliran pada sungai bawah tanah kita mengenal tiga macam komponen aliran seperti yang sudah dijelaskan pada pembahasan diatas yaitu diffuse, fissure, dan conduit, maka hidrograf banjir pada sungai permukaan pun mempunyai tiga komponen aliran utama yang identik yaitu aliran dasar (baseflow) yang setara dengan diffuse, aliran antara (interflow-setara fissure), dan aliran permukaan (channel flow-setara conduit). Konsep ini diantaranya dikenalkan oleh Schulz (1976) yang menganggap suatu akuifer sebagai suatu media penyimpan air yang setelah kejadian banjir akan berangsur-angsur melepaskan tiga komponen simpanan airnya seiring fungsi waktu, seperti yang ditunjukkan pada Gambar 3.

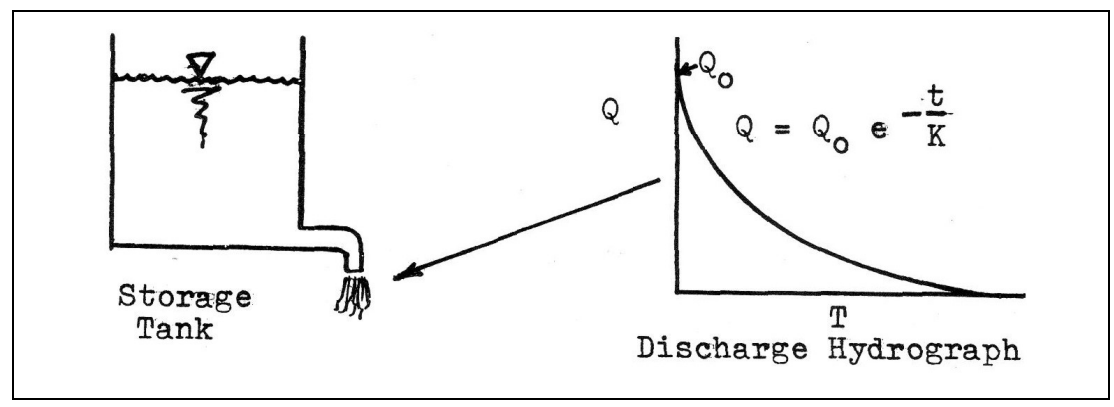


Adji, T. N., Sudarmadji, Woro, S. Hendrayana, H.. 2006. The Distribution of Flood Hydrograph Recession Constant Of Bribin River For Gunung Sewu Karst Aquifer Characterization. GunungSewu-Indonesian Cave and Karst Journal (Vol.2. No.2)

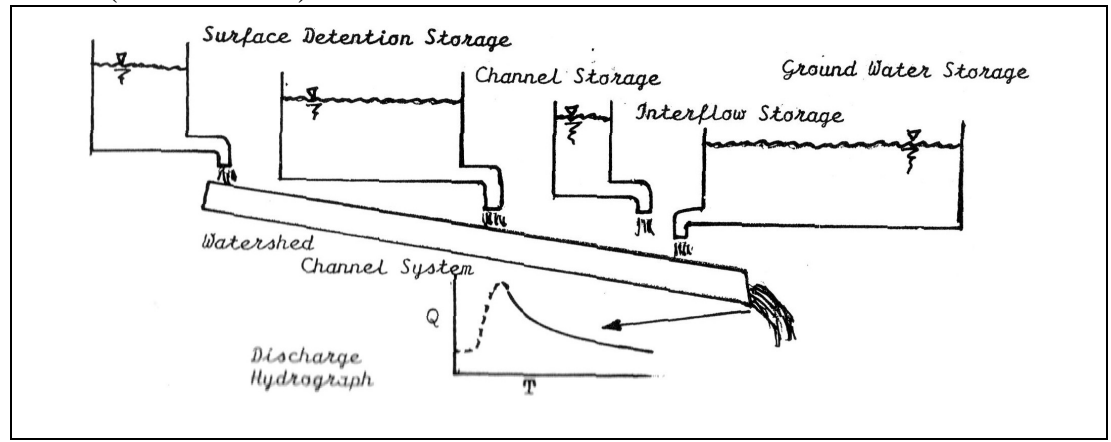

Gambar 3. Pelepasan simpanan air akuifer sebagai komponen aliran (Schulz, 1976)

Kurva resesi (Gambar 3-atas) merupakan bagian dari suatu hidrograf banjir (Gambar 3bawah) pada sungai bawah tanah setelah tidak ada hujan, sehingga debit aliran turun atau akuifer melepaskannya komponen alirannya. Slope atau kemiringan dari kurva resesi semakin menjauhi puncak banjir akan semakin datar karena aliran conduit sudah dilepaskan sehingga aliran diffuse menjadi dominan. Periode kurva resesi ini terus berlangsung sampai terjadi kejadian banjir lagi. Jika mengacu pada Gambar 3, pada periode kurva resesi ini terjadi tiga kali pelepasan oleh masing-masing komponen aliran yaitu diffuse, fissure, dan conduit, yang jike kemudian kita namakan segmen resesi tentunya mempunyai slope yang berbeda-beda pula. Segmen resesi dapat dipilih dari suatu hidrograf banjir dapat dianalisis secara invividu atau bersama-sama untuk memperoleh pemahaman komponen-komponen aliran yang berpengaruh terhadap karakteristik aliran mantab (baseflow). Secara tradisional, analisis dilakukan dengan pendekatan grafikal tetapi pada saat ini lebih cenderung menggunakan model matematis. Masing-masing segmen resesi sering diangap sebagai penurunan secara eksponensial, seperti halnya yang ada pada fenomena fisika seperti aliran panas, difusi, atau radioaktif, yang diformulasikan sebagai berikut :

$$
Q_{t}=Q_{0} e^{-\alpha t}
$$

dimana $Q_{t}$ is adalah debit aliran pada waktu $t, Q_{0}$ adalah debit awal pada segmen resesi, dan $\alpha$ adalah suatu konstanta. Selanjutnya, $e^{-\alpha}$ pada rumus (1) dapat diganti dengan $k$, yang oleh hidrolog dikenal sebagai konstanta resesi (recession constant atau depletion factor), yang jamak digunakan sebagai indikator keberlangsungan aliran dasar (Nathan and McMahon, 1990). Dari hasil penelitian, mereka membuat julat nilai konstanta resesi harian bervariasi dari 0,2-0,8 untuk channel flow; 0,7-0,94 untuk intermediate flow; dan 0,93-0,995 untuk baseflow. Semakin besar nilai kontanta resesi, maka dominasi aliran dasar (baseflow) pada sungai bawah tanah adalah semakin besar.

\section{Pemilihan Lokasi Dan Aplikasi Konstanta Resesi Sungai Bribin}

Terminologi Sungai Bribin (MacDonald and Partners, 1984, Fakultas Kehutanan UGM, 1993) yang menganggap Gua Bribin sebagai outlet, bermula dari Sungai permukaan Pentung yang masuk ke ponor di daerah Sawah Ombo, Tambakromo, yang kemudian ditemui lagi di Gua Jomblangan, kemudian di Gua Gilap, Luweng Jomblangbanyu, Luweng Jurang Jero, dan terakhir di Gua Bribin dengan debit ke arah hilir semakin besar, serta sistem bocorannya yang dapat dijumpai di Gua Ngreneng (Gambar 4). 
Adji, T. N., Sudarmadji, Woro, S. Hendrayana, H.. 2006. The Distribution of Flood Hydrograph Recession Constant Of Bribin River For Gunung Sewu Karst Aquifer Characterization. GunungSewu-Indonesian Cave and Karst Journal (Vol.2. No.2)

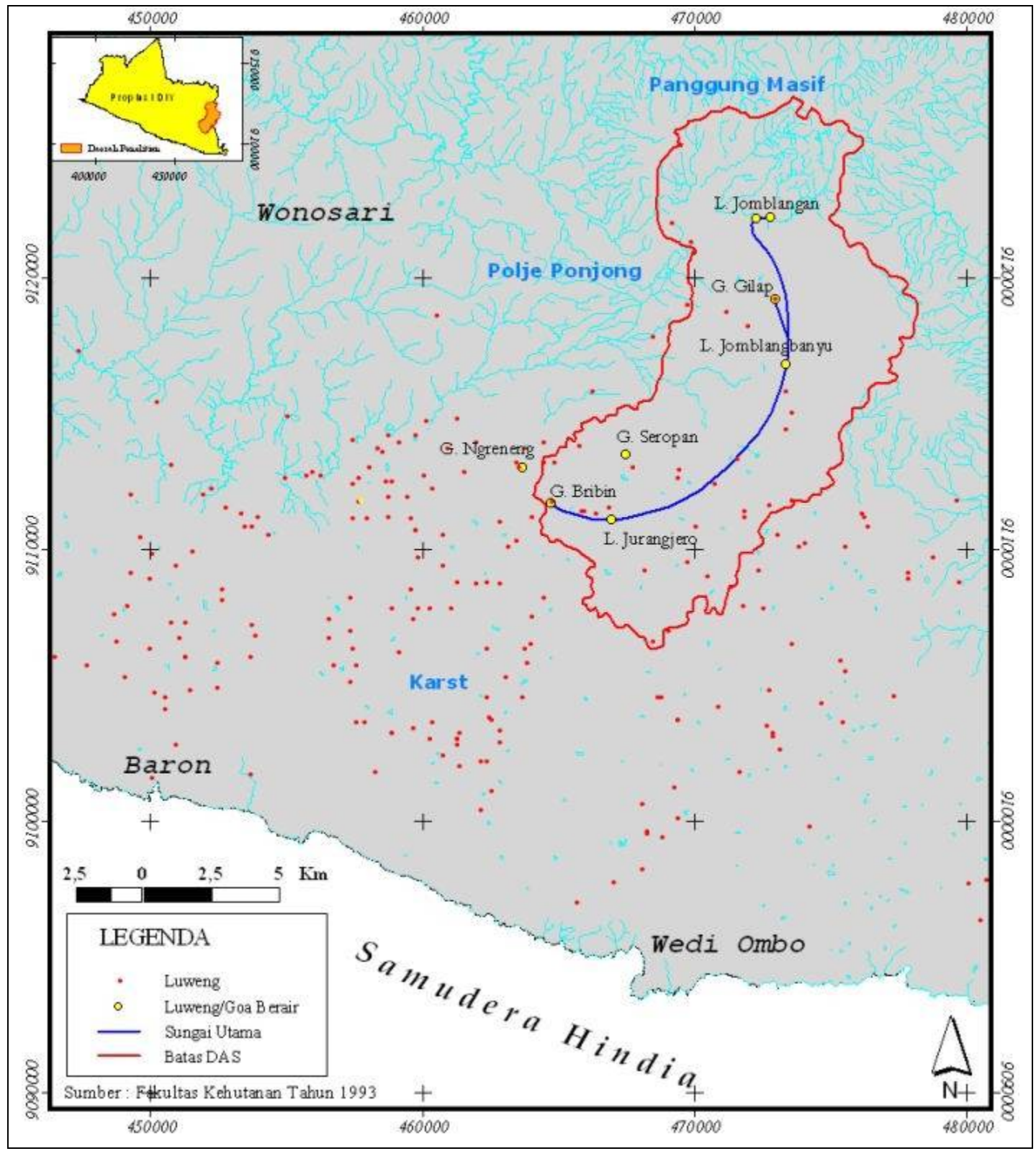

Gambar 3. Sungai Bawah Tanah Bribin Fakultas Kehutanan (1993)

Seperti kita ketahui, Sungai Bribin bernilai sangat strategis bagi penyediaan air sebagian besar penduduk kabupaten Gunung Kidul yang tinggal pada kawasan karst. Pada gua ini, debit minimum terukur di musim kemarau sekitar 1500 liter/detik, sementara pada musim penghujan, debit puncak dapat mencapai lebih dari 2000 liter/detik (MacDonald and Partners, 1984). Penelitian Fakultas Kehutanan (1993) menyebutkan bahwa dari total debit yang dijumpai pada Sungai Bribin, baru sekitar 80 liter/detik yang sudah dimanfatkan dan didistribusikan untuk memenuhi kebutuhan domestik penduduk sekitar. Akhir-akhir ini, kerjasama antara Pemerintah Provinsi (Pemprov) Daerah Istimewa Yogyakarta (DIY), Kab Gunung Kidul, BATAN, Kementerian Ristek, BMBF dan Universitas Kalsruhe, Jerman sudah memulai pemboran dan membuat bendung bawah tanah sistem mikrohidro dengan ketinggian $6 \mathrm{~m}$ dan luas $15 \mathrm{~m}^{2}$ yang terletak sekitar $1 \mathrm{~km}$ pada arah downstream bendungan Bribin (lama) yang disajikan pada Gambar 
Adji, T. N., Sudarmadji, Woro, S. Hendrayana, H.. 2006. The Distribution of Flood Hydrograph Recession Constant Of Bribin River For Gunung Sewu Karst Aquifer Characterization. GunungSewu-Indonesian Cave and Karst Journal (Vol.2. No.2)

1.5 diatas. Bendungan baru ini diharapkan dapat menghasilkan listrik sebesar 250 s.d. $300 \mathrm{KW}$ yang kemudian akan digunakan untuk meningkatkan kapasitas layanan distribusi airtanah karst ini menjadi dua kali lipat dari sebelumnya (Sinar Harapan, 2004). Melihat uraian tersebut, tampak bahwa harapan terhadap kelangsungan sumberdaya airtanah Sungai Bribin sangat besar mengingat besarnya investasi yang mencapai 2 trilyun rupiah (Suara Merdeka, 2004).

Permasalahannya, sampai saat ini penelitian yang mengkhususkan pada perilaku hidrologis Sungai Bribin secara time-series belum tersedia. Penelitian yang sering dilakukan hanya bersifat satu kali pengukuran sehingga tidak dapat digunakan sebagai penciri karakateristik akuifer. Selanjutnya, tujuan utama peneliian ini adalah menghitung konstanta resesi pada beberapa tik yang mewakili Sungai Bribin atas dasar pencatatan debit selama satu tahun penuh. Kemudian, dari hidrograf banjir yang tercatat, akan dapat diketahui parameter-parameter penciri respon hujan terhadap akuifer karst Sungai Bribin. Lebih jauh lagi, nilai konstanta resei akan sangat diperlukan dalam menghitung prosentase aliran mantap/dasar (base flow) dari suatu akuifer secara otomatis pada waktu pencatatan yang panjang ((Eckhardt, 2005). Sehingga, pengetahuan tentang konstanta resesi dan besarnya aliran dasar akan dapat digunakan untuk memonitor keberlangsungan media penyimpan air karst di daerah tangkapan hujan Sungai Bribin, pada masamasa mendatang.

\section{Metode Penelitian}

\section{Distribusi alat pengukur}

Batas daerah penelitian yang digunakan adalah asumsi batas DAS bawah tanah Bribin yang yang didelineasi oleh Fakultas Kehutanan (1993). Tidak semua gua yang dilewati Sungai Bribin dipasang alat pencatat hubungan tinggi muka air dan waktu, tetapi dipilih atas dasar distribusi dan kemudihan akses untuk masuk ke dalam gua. Posisi alat ukur selanjutnya disajikan pada Gambar 4. Selanjutnya, beberapa hal yang perlu diperhatikan dalam menentukan posisi alat pengukuran diantaranya adalah:

(a) Persebarannya untuk mewakili luasan tertentu. Sebagai contoh pada Gambar 4 terlihat bahwa 3 buah penakar hujan ditempatkan sedemikian rupa sehingga persebaran hujan di daerah hulu, tengah, dan hilir dapat terwakili.

(b) Kemudahan aksesibilitas. Pada Gambar 4, persebaran stasiun pencatat aliran sungai bawah tanah sepertinya tidak tersebar merata. Hal ini diakibatkan sulitnya memperoleh gua yang memiliki akses yang mudah untuk diamati pada waktu-waktu yang dikehendaki. Sebagai contoh, lokasi yang paling ideal secara spasial untuk penempatan stasium aliran adalah di Luweng Jomblang Banyu, tetapi mengingat aksesibilitas menuju sungai yang membutuhkan waktu diatas 12 jam menyebabkan lokasi ini tidak memungkinkan untuk dipasang stasiun aliran. Selain itu titik-titik di L. Jomblangan, L. Jurangjero, dan sinkhole Petung tidak memungkinkan untuk dipasang alat pencatat tinggi muka air.

\section{Peralatan yang digunakan}

Selanjutnya, beberapa peralatan yang digunakan pada penelitian ini adalah :

a) Penakar hujan (rain gauge). Penelitian perilaku sungai bawah tanah mensyaratkan penakar hujan otomatis sehingga tidak perlu setiap hari mencatat secara manual. Beberapa tipe penakar hujan yang dipasang pada penelitian penulis adalah seperti yang disajikan pada Gambar 5. 
Adji, T. N., Sudarmadji, Woro, S. Hendrayana, H.. 2006. The Distribution of Flood Hydrograph Recession Constant Of Bribin River For Gunung Sewu Karst Aquifer Characterization. GunungSewu-Indonesian Cave and Karst Journal (Vol.2. No.2)

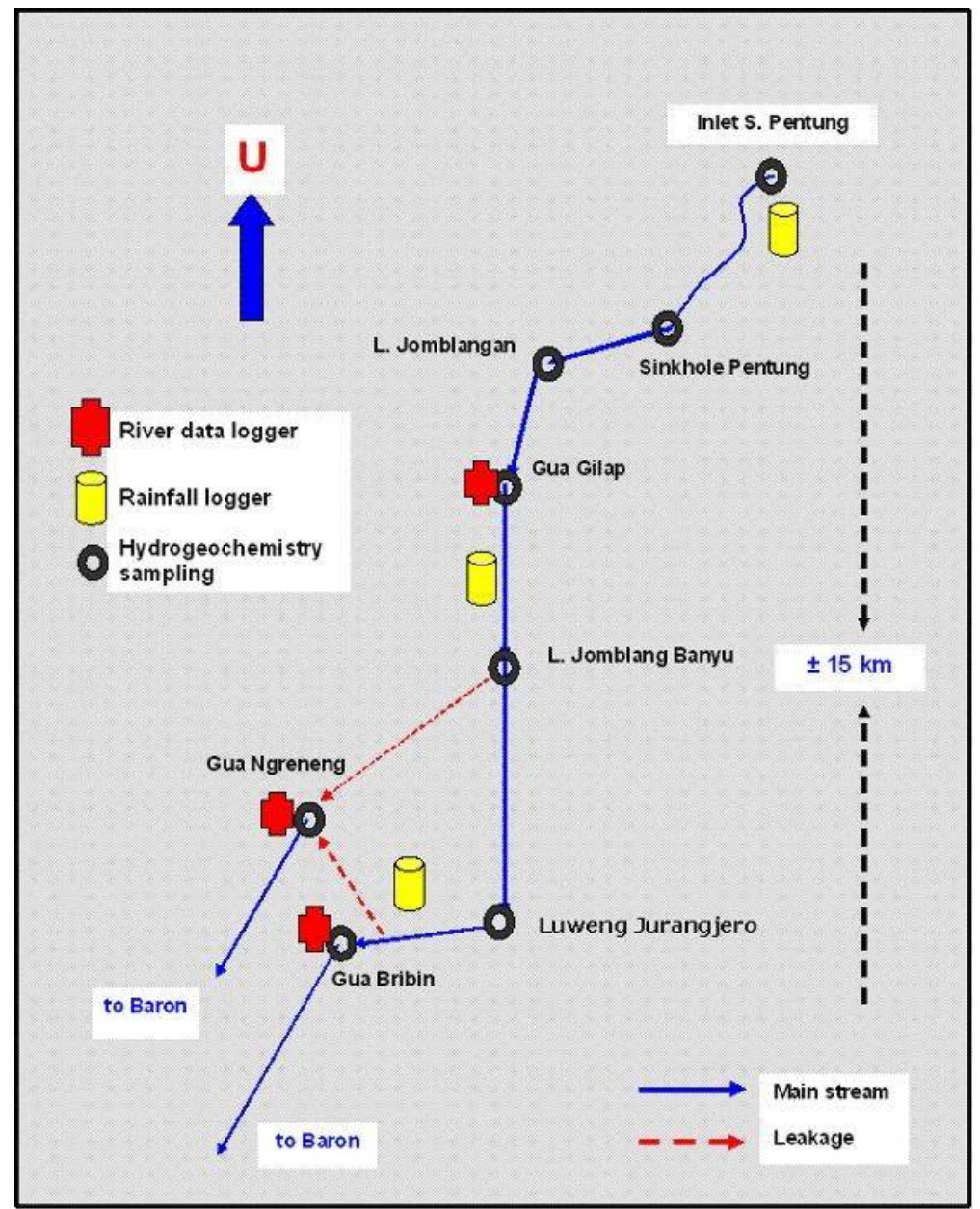

Gambar 4. Distribusi penempatan alat ukur
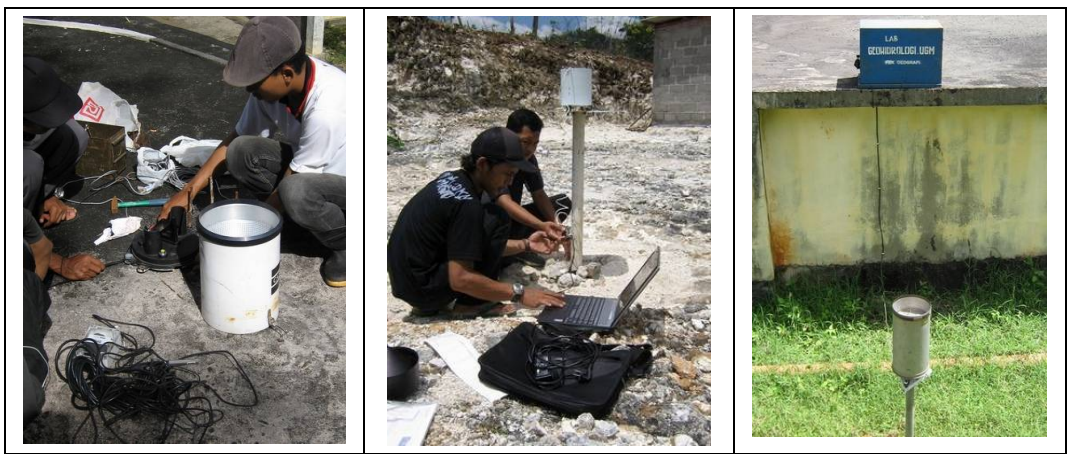

Gambar 5. Penakar hujan otomatik tipe Castella (hulu DAS Bribin-kiri); Onset-HOBO RG3M (tengah DAS Bribin-tengah); semi otomatik (hilir DAS Bribin-kanan)

b) Alat pencatat tinggi muka air (water level data logger). Untuk mengetahui fluktuasi tinggi muka air tiap 30 menit secara time series, diperlukan instalasi stasiun aliran sekaligus pemasangan alat pencatat tinggi muka air, seperti yang disajikan pada Gambar 6 . 
Adji, T. N., Sudarmadji, Woro, S. Hendrayana, H.. 2006. The Distribution of Flood Hydrograph Recession Constant Of Bribin River For Gunung Sewu Karst Aquifer Characterization. GunungSewu-Indonesian Cave and Karst Journal (Vol.2. No.2)
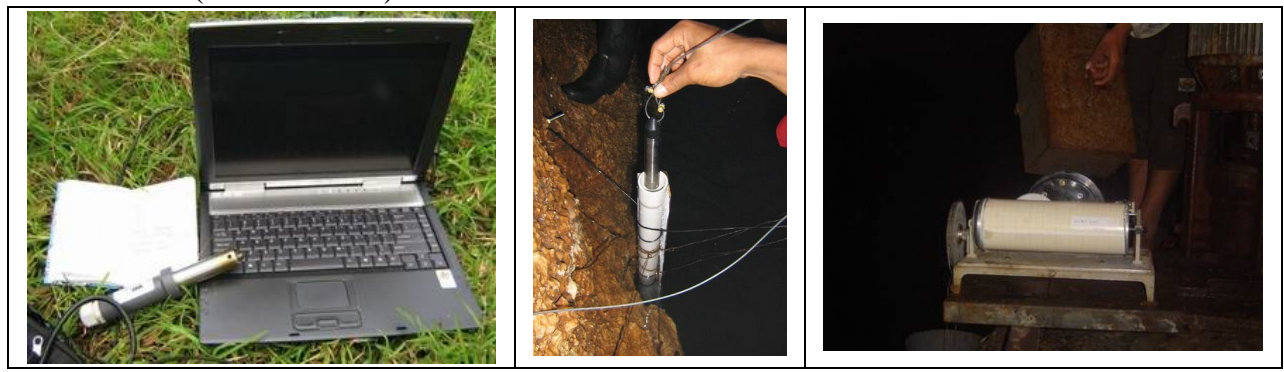

Gambar 6. Water Level Data Logger yang dipasang di Gua Gilap (kiri); instalasi stasiun aliran di Gua Ngreneng (tengah); automatic water level recorder -AWLR di Gua Bribin (kanan).

\section{Pengukuran debit dan pembuatan kurva debit vs tinggi muka air}

Setelah alat pencatat fluktuasi tinggi muka air terpasang, pada periode-periode tertentu dilakukan pengukuran debit untuk memperoleh kurva atau persamaan antara tinggi muka air dan debit (stage-discharge rating curve) aliran Sungai Bribin, sehingga secara time-series selama 1 tahun debit aliran dapat diperoleh atas dasar fluktuasi tinggi muka air. Ilustrasi pengukuran debit dengan metode velocity area method dengan bantuan alat current meter pada gua-gua yang terpasang alat pencatat tinggi muka air disajikan pada Gambar 7.

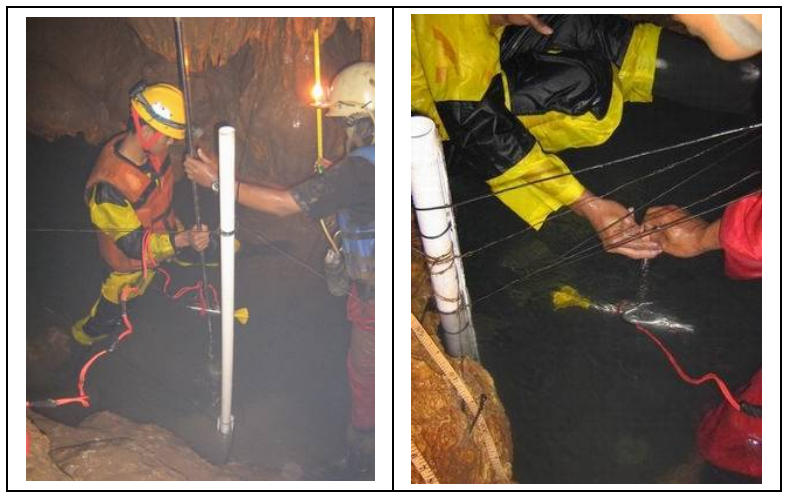

Gambar 7. Pengukuran debit aliran dengan current meter di Gua Gilap (kiri) dan Gua Ngreneng (kanan)

\section{Pemilihan banjir dan perhitungan konstanta resesi}

Pada gua-gua yang dilewati sungai bawah tanah Bribin, terjadi puluhan kali banjir pada periode satu musim hujan pada masing-masing gua yang diamati, sehingga analisis tidak dilakukan pada semua kejadian banjir. Pemilihan banjir yang dianalisis didasarkan pada keterwakilan nilai waktu dari puncak banjir sampa aliran (tb=time to base flow) sehingga banjirbanjir yang sangat kecil atau sangat pendek (minimum runoff atau intermediate flow) dapat diabaikan karena secara matematis tidak valid jika dipaksakan diukur konstanta resesinya (Schulz,1976). Selanjutnya, konstanta resesi banjir terpilih pada berbagai komponen aliran dicari dengan persamaan:

$Q(t)=Q\left(t_{o}\right) e^{-k\left(t-t_{0}\right)}$

Dimana $\mathrm{k}$ adalah konstanta resesi pada suatu sistem akuifer, $\mathrm{t}$ adalah waktu pada debit ke $\mathrm{t}$, dan $\mathrm{t}_{0}$ adalah waktu pada debit awal resesi. Kemudian jika pada skala semi-log rumus ini dianggap linier, maka: 
Adji, T. N., Sudarmadji, Woro, S. Hendrayana, H.. 2006. The Distribution of Flood Hydrograph Recession Constant Of Bribin River For Gunung Sewu Karst Aquifer Characterization. GunungSewu-Indonesian Cave and Karst Journal (Vol.2. No.2)

$\ln Q(t)=-k\left(t-t_{0}\right)+\ln Q\left(t_{0}\right)$ (3), atau

$k=-1 / t-t_{o} \ln \left(Q_{t} / Q_{o}\right)$

\section{Hasil dan Pembahasan}

Pengukuran debit aliran pada lokasi alat pencatat tinggi muka air sepanjang tahun dilakukan pada saat-saat tertentu sehingga mewakili berbagai kondisi tinggi muka air. Pengukuran debit dilakukan sebanyak 9 kali di Gua Gilap, 11 kali di Gua Ngreneng, dan 15 kali di Gua Bribin, yang hasilnya secara rinci ditunjukkan pada Tabel 1.

Tabel 1. Pengukuran debit aliran pada berbagai kondisi tinggi muka air

\begin{tabular}{|c|c|c|c|c|c|c|c|c|}
\hline \multicolumn{3}{|c|}{ Gua Bribin } & \multicolumn{3}{|c|}{ Gua Gilap } & \multicolumn{3}{|c|}{ Gua Ngreneng } \\
\hline $\begin{array}{c}\text { Tanggal } \\
\text { pengukuran }\end{array}$ & $\begin{array}{l}\text { Tinggi muka } \\
\text { air }(\mathrm{m})\end{array}$ & $\begin{array}{l}\text { Debit aliran } \\
\text { (It/dt) }\end{array}$ & $\begin{array}{c}\text { Tanggal } \\
\text { pengukuran }\end{array}$ & $\begin{array}{l}\text { Tinggi muka } \\
\text { air }(\mathrm{m})\end{array}$ & $\begin{array}{l}\text { Debit aliran } \\
\text { (lt/dt) }\end{array}$ & $\begin{array}{c}\text { Tanggal } \\
\text { pengukuran }\end{array}$ & $\begin{array}{l}\text { Tinggi muka } \\
\text { air }(\mathrm{m})\end{array}$ & $\begin{array}{l}\text { Debit aliran } \\
\text { (lt/dt) }\end{array}$ \\
\hline $18 / 1 / 00$ & 0.98 & 1297.19 & $28 / 4 / 06$ & 1.32 & 294.10 & $20 / 4 / 06$ & 1.80 & 545.96 \\
\hline $28 / 1 / 00$ & 1.06 & 1277.65 & $23 / 5 / 06$ & 0.72 & 44.52 & $26 / 4 / 06$ & 1.61 & 488.33 \\
\hline $5 / 2 / 00$ & 1.61 & 1939.94 & $21 / 6 / 06$ & 0.57 & 35.24 & $22 / 5 / 06$ & 1.21 & 283.11 \\
\hline $20 / 2 / 00$ & 1.37 & 1605.24 & $19 / 7 / 06$ & 0.34 & 25.23 & $22 / 6 / 06$ & 1.17 & 263.61 \\
\hline $23 / 2 / 00$ & 1.27 & 1480.61 & $24 / 8 / 06$ & 0.16 & 17.26 & $19 / 7 / 06$ & 0.97 & 219.00 \\
\hline $4 / 3 / 00$ & 1.10 & 1346.78 & $21 / 9 / 06$ & 0.09 & 8.91 & $23 / 8 / 06$ & 0.71 & 140.71 \\
\hline $8 / 3 / 00$ & 0.80 & 1001.15 & $16 / 11 / 06$ & 0.08 & 6.93 & $20 / 9 / 06$ & 0.62 & 123.57 \\
\hline $13 / 3 / 00$ & 1.33 & 1571.08 & $21 / 12 / 06$ & 0.15 & 12.99 & $15 / 11 / 06$ & 0.38 & 75.73 \\
\hline $18 / 3 / 00$ & 0.80 & 923.67 & $22 / 3 / 07$ & 0.99 & 122.51 & $20 / 12 / 06$ & 0.43 & 100.61 \\
\hline $22 / 3 / 00$ & 0.97 & 1176.54 & & & & $23 / 2 / 06$ & 1.15 & 189.32 \\
\hline $27 / 3 / 00$ & 1.36 & 1732.06 & & & & $30 / 3 / 06$ & 0.98 & 100.84 \\
\hline $1 / 4 / 00$ & 0.86 & 1027.89 & & & & & & \\
\hline $10 / 4 / 00$ & 0.87 & 979.63 & & & & & & \\
\hline $25 / 4 / 00$ & 1.44 & 1743.91 & & & & & & \\
\hline $30 / 4 / 00$ & 0.94 & 1123.09 & & & & & & \\
\hline
\end{tabular}

Sumber : Pengukuran lapangan th. 2006-2007 (Gilap \& Ngreneng), Suryanta, 2001 (Bribin)

Selanjutnya, analisis regresi dilakukan untuk memperoleh rumus kurva aliran (stage discharge rating curve), seperti yang disajikan pada Gambar 8. Dengan rumus kurva aliran ini maka pada masa-masa mendatang, perhitungan debit aliran dapat dilakukan hanya dengan melihat tinggi muka air pada mistar ukur terpasang didekat alat pencatat tinggi muka air. Rumus rating curve yang dihasilkan yaitu :

- Gua Gilap,

$$
y=107.44 x^{1.1041}
$$

- Gua Ngreneng,

$$
y=213.04 x^{1.1584}
$$

- Gua Bribin,

$$
y=1204.5 x^{1.0103}
$$

dimana, y adalah debit aliran (lt/dt) dan x adalah tinggi muka air (m)

Kemudian, rumus ini digunakan untuk menghitung debit aliran sepanjang tahun ( 1 tahun) dengan interval waktu pencatatan tinggi muka air tiap 30 menit sekali. Hasil perhitungan disajikan pada Gambar 9. 
Adji, T. N., Sudarmadji, Woro, S. Hendrayana, H.. 2006. The Distribution of Flood Hydrograph Recession Constant Of Bribin River For Gunung Sewu Karst Aquifer Characterization. GunungSewu-Indonesian Cave and Karst Journal (Vol.2. No.2)
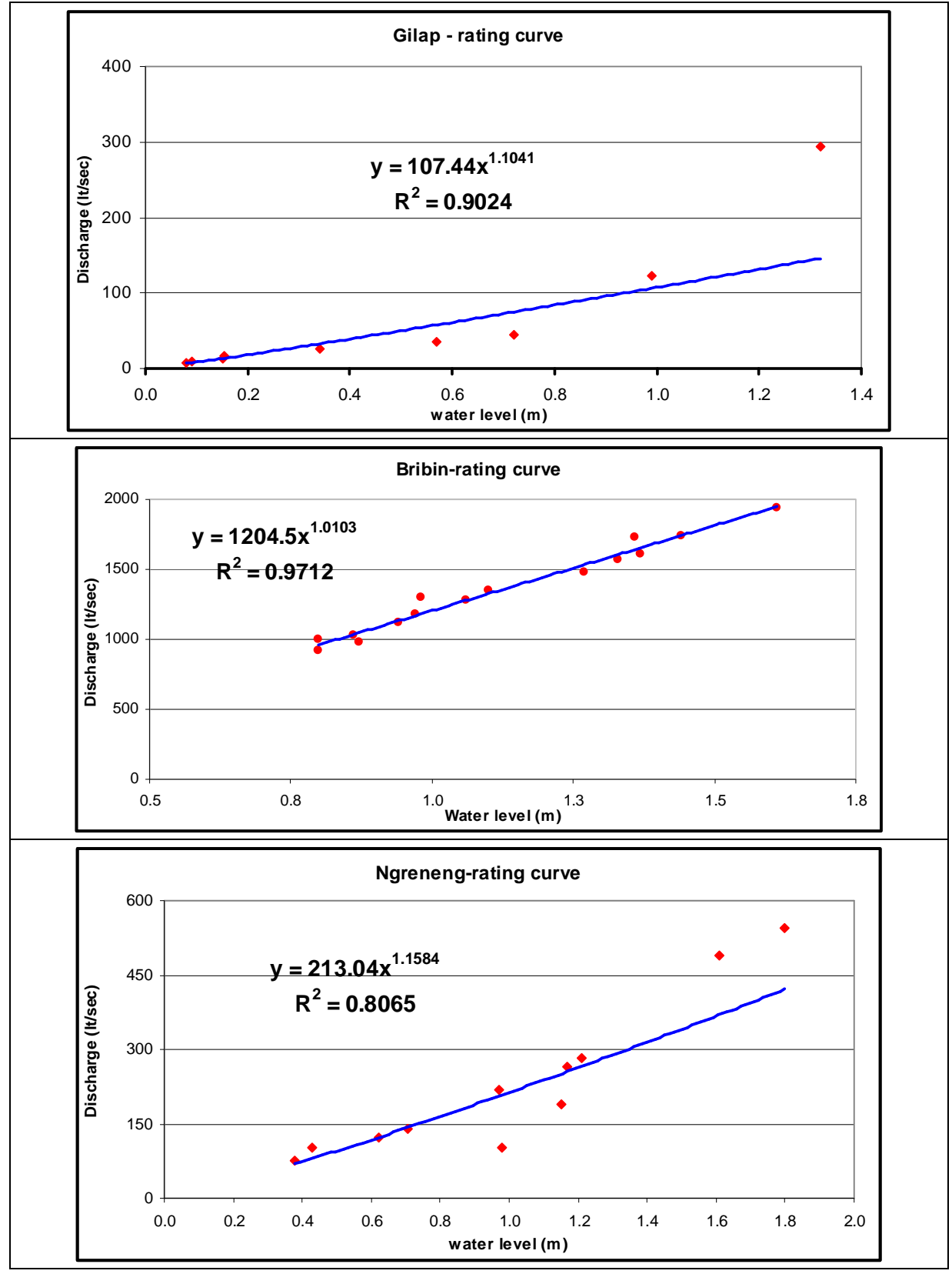

Gambar 8. Hubungan debit-TMA di Gilap-hulu, Bribin-bawah, dan Ngreneng-bocoran 
Adji, T. N., Sudarmadji, Woro, S. Hendrayana, H.. 2006. The Distribution of Flood Hydrograph Recession Constant Of Bribin River For Gunung Sewu Karst Aquifer Characterization. GunungSewu-Indonesian Cave and Karst Journal (Vol.2. No.2)
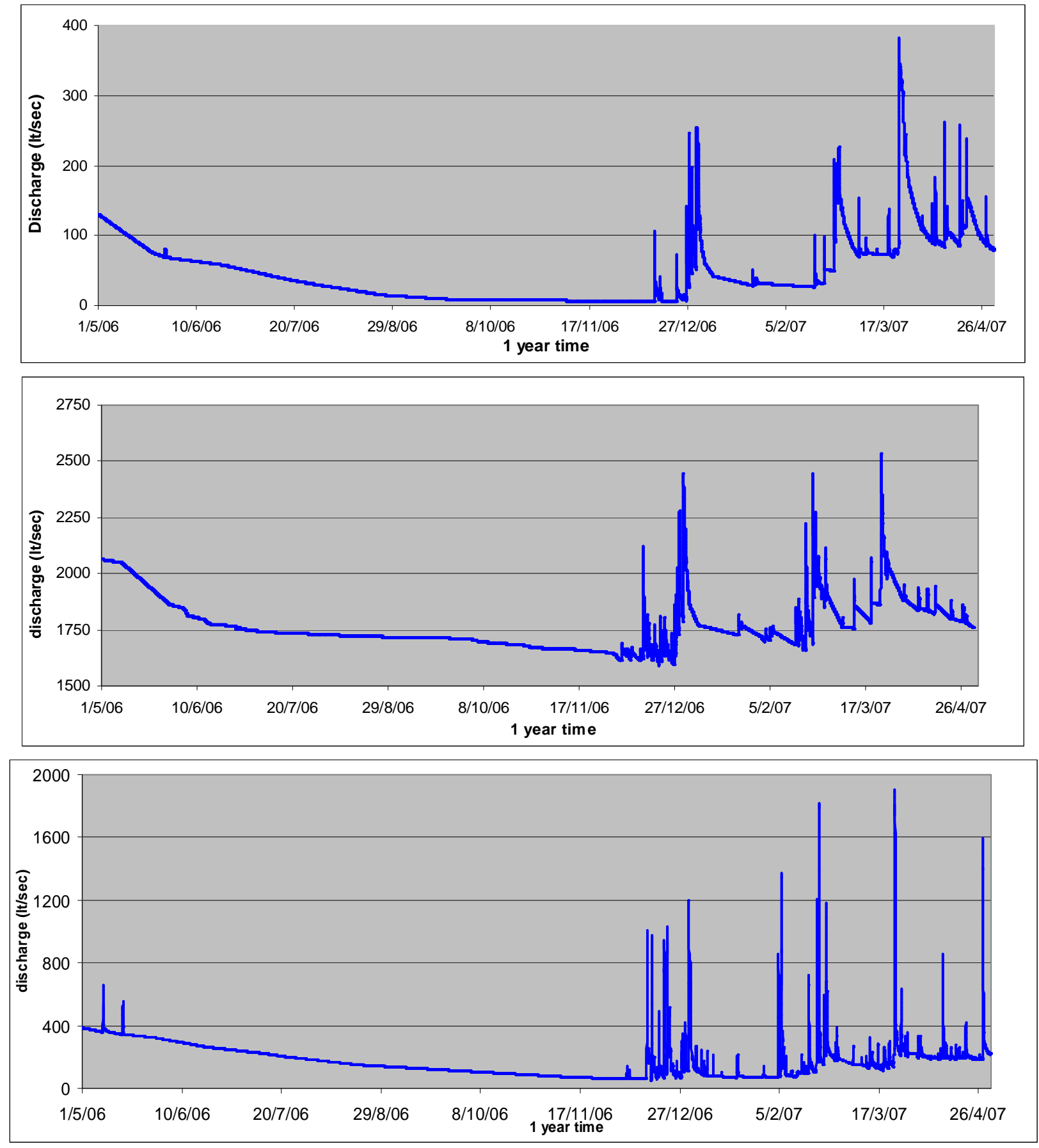

Gambar 9. Fluktuasi debit 1 tahun Gua Gilap (atas), Bribin (tengah), dan Ngreneng (bawah)

Jumlah kejadian banjir yang terjadi di Gua Gilap, Bribin, dan Ngreneng secara berturutan adalah 32, 37, 70 kejadian banjir. Perhitungan resesi pada masing-masing komponen aliran dilakukan setelah dilakukan pemilihan banjir-banjir yang memenuhi syarat, yaitu banjir dengan debit yang tidak terlalu kecil dan yang mewakili berbagai variasi time to baseflow (Tb) yaitu waktu antara puncak banjir sampai dengan waktu hilang atau habisnya komponen aliran conduit dan fissure, dan hanya tersisa komponen aliran diffuse. Kemudian, hasil perhitungan nilai 
Adji, T. N., Sudarmadji, Woro, S. Hendrayana, H.. 2006. The Distribution of Flood Hydrograph Recession Constant Of Bribin River For Gunung Sewu Karst Aquifer Characterization. GunungSewu-Indonesian Cave and Karst Journal (Vol.2. No.2)

konstanta resesi, waktu menuju banjir dan waktu menuju baseflow di gua Gilap, Ngreneng dan Bribin diringkas dan disajikan pada Tabel 2.

Tabel 2. Ringkasan julat nilai konstanta resesi dan paramater banjir Sungai Bribin

\begin{tabular}{|l|c|c|c|c|c|}
\hline \multicolumn{1}{|c|}{ Nama gua } & $\mathbf{K}_{\mathbf{c}}$ & $\mathbf{K}_{\mathbf{i}}$ & $\mathbf{K}_{\mathbf{b}}$ & $\mathbf{T}_{\mathbf{p}}$ (jam) & $\mathbf{T}_{\mathbf{b}}$ (jam) \\
\hline Gua Gilap & $\begin{array}{c}0,14-0,88 \\
\text { (rerata=0,463) }\end{array}$ & $\begin{array}{c}0,39-0,92 \\
(\text { rerata=0,767) }\end{array}$ & $\begin{array}{c}0,94-0,99 \\
(\text { rerata }=0,994)\end{array}$ & $\begin{array}{c}1,5-5 \\
\text { (rerata=3,03) }\end{array}$ & $\begin{array}{c}6-192 \\
\text { (rerata=36,7) }\end{array}$ \\
\hline Gua Bribin & $\begin{array}{c}0,15-0,73 \\
\text { (rerata=0,576) }\end{array}$ & $\begin{array}{c}0,31-0,95 \\
(\text { rerata=0,822) }\end{array}$ & $\begin{array}{c}0,98-0,99 \\
(\text { rerata }=0,998)\end{array}$ & $\begin{array}{c}2-13 \\
\text { (rerata=6,35) }\end{array}$ & $\begin{array}{c}5-192 \\
\text { (rerata=36,3) }\end{array}$ \\
\hline Gua Ngreneng & $\begin{array}{c}0,19-0,75 \\
\text { (rerata=0,333) }\end{array}$ & $\begin{array}{c}0,74-0,97 \\
(\text { rerata=0,876) }\end{array}$ & $\begin{array}{c}0,98-0,99 \\
(\text { rerata }=0,997)\end{array}$ & $\begin{array}{c}2,5-7,5 \\
\text { (rerata=4,94) }\end{array}$ & $\begin{array}{c}9-240 \\
\text { (rerata=52,8) }\end{array}$ \\
\hline
\end{tabular}

$* \mathrm{~K}_{\mathrm{c}}=$ konstanta resesi conduit; $\mathrm{K}_{\mathrm{i}}=$ konstanta resesi fissure; $\mathrm{K}_{\mathrm{b}}=$ konstanta resesi diffuse

Dari ringkasan data yang disajikan pada Tabel 2, terlihat bahwa variasi nilai konstanta resesi untuk komponen aliran diffuse, fissure, dan conduit pada tiga gua di Sungai Bribin adalah sangat tinggi. Rata-rata nilai konstanta resesi aliran diffuse tertinggi terjadi di Gua Bribin $(0,998)$ dengan variasi nilai $\mathrm{K}_{\mathrm{b}}$ yang kecil mengindikasikan bahwa dominasi diffuse flow pasca banjir pada skala waktu yang pendek maupun panjang masih bagus. Hal ini terbukti dengan tidak pernah keringnya Gua Bribin pada puncak musim kemarau dengan debit minimum terukur masih diatas 1500 lt/dt. Sementara itu Gua Gilap mempunyai rerata konstanta resesi diffuse yang paling kecil, dengan variasi nilai sepanjang musim banjir cukup besar $(0,94-0,99)$. Hal ini berpengaruh pada perilaku banjir di Gilap yang sangat cepat $(\mathrm{Tp}=3 \mathrm{jam})$, yang kemudian debit turun lagi mencapai kondisi aliran dasar relatif cepat $(\mathrm{Tb}=36 \mathrm{jam})$ dibanding gua-gua yang lain. Karena nilai $\mathrm{K}_{\mathrm{b}}$ yang lebih kecil dibanding Gua Bribin dan Ngreneng, kondisi Gua Gilap pada musim kemarau mencapai debit minimum yang sangat kecil yaitu sekitar 6 liter/detik pada 7 Desember 2006 (Gambar 9). Sementara itu, Gua Ngreneng yang diyakini sebagai bocoran Sungai Bribin, akuifernya mempunyai sifat pelepasan komponen aliran diffuse yang hampir sama dengan Gua Bribin (0,98-0,99), meskipun debit minimum tercatat hanya sekitar 60 liter/detik yang kemungkinan lebih disebabkan oleh morfologi lorong guanya yang lebih kecil dibanding yang ada di Gua Bribin. Gua Ngreneng juga mempunyai rerata waktu kembali ke aliran dasar yang paling lama $(52,8$ jam $)$.

Selanjutnya, nilai konstanta resesi untuk aliran saluran atau conduit $\left(\mathrm{K}_{\mathrm{c}}\right)$ menunjukkan bahwa Gua Ngreneng dan Gua Gilap mempunyai resesi yang curam dengan nilai rata-rata selama periode banjir dibawah 0,5. Menurut Schulz (1976), nilai resesi saluran yang kecil mempunyai karakteristik banjir yang lebih cepat dibanding jika nilai $\mathrm{K}_{\mathrm{c}}$ nya lebih besar. Dalam kasus ini, Gua Ngreneng mempunyai nilai rata-rata $K_{c}$ yang paling kecil $(0,333)$ yang kemungkinan disebabkan pada saat-saat hujan puncak memperoleh aliran permukaan setempat, karena lokasi gua ini yang berada pada suatu cekungan, sementara nilai $\mathrm{T}_{\mathrm{b}}$ tercatat tetap lama, karena terpengaruh oleh karakteristik banjir Sungai Bribin. Sementara itu, nilai konstanta resesi fissure atau aliran antara $\left(\mathrm{K}_{\mathrm{i}}\right)$ pada tiga gua di daerah penelitian tidak menunjukkan perbedaan yang cukup berarti dengan julat yang hampir seimbang, yang menunjukkan bahwa pola fissure (retakan berukuran menengah) pada akuifer karst daerah tangkapan Sungai Bribin adalah hampir identik. Sebagai tambahan informasi, Gua Gilap mempunyai rerata nilai $\left(\mathrm{K}_{\mathrm{i}}\right)$ yang paling rendah $(0,767)$ dibanding di Gua Bribin dan Ngreneng $(0,822$ dan 0,876$)$. 
Adji, T. N., Sudarmadji, Woro, S. Hendrayana, H.. 2006. The Distribution of Flood Hydrograph Recession Constant Of Bribin River For Gunung Sewu Karst Aquifer Characterization. GunungSewu-Indonesian Cave and Karst Journal (Vol.2. No.2)

Melihat angka-angka terkait konstanta resesi pada berbagai komponen aliran, tampak bahwa Gua Gilap yang mewakili Sungai Bribin bagian hulu mempunyai respon yang paling cepat terhadap hujan, serta mempunyai rerata nilai $\mathrm{K}_{\mathrm{b}}$ yang lebih rendah dibanding Gua Bribin yang berarti kemampuan untuk menyimpan air infiltrasi pada permukaan karst sedikit lebih rendah dibanding kondisi di permukaan daerah hilir (Gua Bribin), meskipun kisaran angka $\mathrm{K}_{\mathrm{b}}$ di Gua Gilap masih tergolong sangat baik $(>0,9)$. Selain itu, debit saluran yang ada di Gua Gilap mempunyai respon yang cepat terhadap kejadian hujan di daerah tangkapannya $\left(\mathrm{T}_{\mathrm{p}}=3\right.$ jam $)$, jika dibandingkan dengan Gua Ngreneng dan Bribin. Dari nilai ini, kemungkinan faktor yang berperan adalah jarak antara batas daerah tangkapan dengan Gua Gilap, ataupun kondisi permukaan di daerah hulu yang mempunyai banyak sinkhole. Hal ini berbeda dengan yang terlihat pada nilai $\mathrm{K}_{\mathrm{b}}$ di Gua Ngreneng yang meskipun lebih kecil daripada yang terhitung di Gua Gilap, tetapi karena letaknya yang lebih ke arah hilir, maka mempunyai nilai $\mathrm{T}_{\mathrm{b}}$ yang lebih lama dibanding Gua Gilap (Tabel 2). Sementara itu, Gua Bribin masih mempunyai dominasi yang lebih banyak dalam hal penyediaan komponen aliran diffuse (jika dilihat dari nilai $\mathrm{K}_{\mathrm{b}}$ ), dibanding gua yang lain.

\section{Daftar Pustaka}

Adji, T.N. dan Haryono, E., 1999. Konflik Antara Pemanfaatan Batugamping dan Konservasi Sumberdaya Air Das Bribin di Wilayah Karst Gunung Sewu, Makalah Lokakarya Nasional Menuju Pengelolaan Sumberdaya Wilayah Berbasis Ekosistem Untuk Mereduksi Konflik Antar Daerah, Yogjakarta, , Fakultas Geografi, Universitas Gadjah Mada, September 1999

Adji, T.N., Haryono, E., Woro, S, 1999, Kawasan Karst dan Prospek Pengembangannya di Indonesia, Seminar PIT IGI di Universitas Indonesia, 26-27 Oktober 1999

Anthony, D.M., Groves, C., Meiman, J., 1997. Preliminary investigations of seasonal changes in the geochemical evolution of Logdson River, Mammoth Cave, Kentucky, Proceedings of the 4th Mammoth Cave Science Conf., Mammoth Cave, KY, 15-23.

Blair,R.W., 2004. Karst Landforms and Lakes, Geomorphology from Space, NASA, USA

Dane, F.C. 1990. Research Methods, Brooks/Cole Publishing Company, Pacific Grove, California

Domenico,P.A. and Schwartz, F.W., 1990. Physical and Chemical Hydrogeology. $2^{\text {nd }}$ Ed. John Wiley \& Sons

Etfimi, R., 2005. Use of hydrochemical studies to identify the recharge sources of karst Spring; example of Poceme springs in Albania, Geophysical Research Abstracts, Vol.7, 04063

Ford, D. and Williams, P. 1992. Karst Geomorphology and Hydrology, Chapman and Hall, London

Gillieson, D., 1996. Caves: Processes, Development, and Management, Blackwell, Oxford

Haryono, E. dan Adji, T.N. 2004. Geomorfologi dan Hidrologi Karst. Yogyakarta: Kelompok Studi Karst, Fakultas Geografi, Universitas Gadjah Mada

Haryono, E., 2001. Nilai Hidrologis Bukit Karst, Makalah pada seminar Nasional, Eko-Hidrolik, 28-29 Maret 2001, Jurusan Teknik Sipil , UGM

Jankowski, J., 2001. Groundwater Environment, Short Course Note, School of Geology, University Of New South Wales, Sydney, Australia

Karimi, H., Raeisi , E., Zare, M. 2003. Hydrodynamic behavior of the Gilan karst spring, west of Zagros, Iran. BCRA Cave and Karst Science. Vol 30 (1) pp 15 - 22

Liu, Z.,Groves,C., Yuan,D., Meiman,J., 2004(a). South China Karst Aquifer Storm-Scale Hydrochemistry, Ground Water. 42, Jul/Agt 2004

Liu, Z.,Groves,C., Yuan,D., Meiman,J., Jiang, D., He, S., Li,Q., 2004(b). Hydrochemical variation during flood pulses in the south-west peak cluster karst : impacts of $\mathrm{CaCO}_{3}-\mathrm{H}_{2} \mathrm{O}-\mathrm{CO}_{2}$ interactions, Hydrological Processess. 18, 2423-2437

MacDonalds and Partners. 1984. Greater Yogyakarta - Groundwater Resources Study. Vol 3C: Cave Survey. Yogyakarta, Directorate General of Water Resources Development Project (P2AT) 
Adji, T. N., Sudarmadji, Woro, S. Hendrayana, H.. 2006. The Distribution of Flood Hydrograph Recession Constant Of Bribin River For Gunung Sewu Karst Aquifer Characterization. GunungSewu-Indonesian Cave and Karst Journal (Vol.2. No.2)

Nathan RJ, McMahon TA, 1990. Evaluation of automated techniques for baseflow and recession analysis. Water Resources Research. 26(7):1465-1473.

Raeisi, R., Karami,G., 1997. Hydrochemographs of Berghan karst spring as indicators of aquifer characteristics, Journal of Cave and Karst Studies 59(3), 112-118

Schulz, E.F., 1976. Problems in Applied Hydrology. Water Resources Publication, Colorado

Sinar Harapan, 2004. Mesin Bor Pembangunan Bendung Gua Bribin Tiba. 18 Juni 2004. www.sinarharapan.co.id/berita/0406/17/nus04.html

Smart, P.L. and Hobbes, S.L., 1986. Characteristics of Carbonate Aquifers: A conceptual basis. In Proceedings, Environmental Problem in Karst Terrains and Their Solution. Bowling Green, KY: National Well Water Association, 1-4

Suara Merdeka, 2004. Warga Gunungkidul Bakal Nikmati Air Bersih. 21 Juni 2004. http://www.suaramerdeka.com/harian/0406/21/ked08.htm

Suryanta, G., 2001. Kajian Karakteristik Hidrograf Satuan Daerah Karst Gunung Kidul (Studi Kasus: Daerah Tangkapan Air Sungai Bawahtanah Bribin, Kabupaten Gunung Kidul, Propinsi DIY), Skripsi Sarjana, Fakultas Geografi, UGM, Yogyakarta

White, W.B., 1988. Geomorphology and Hydrology of Karst Terrain. Oxford University Press, New York

White, W.B., 1993. Analysis of Karst Aquifer. In:Alley, W.M. (editor), regional groundwater Quality. Van Nostrand Reinhold, New York 